\title{
CHANGING ORGANIZATIONAL FORM: DEMUTUALIZATION AND THE PRIVATIZATION OF COMMUNAL WEALTH - AUSTRALIAN CREDIT UNION EXPERIENCES
}
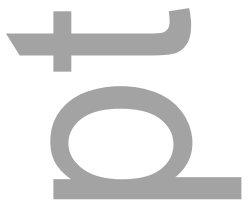

The University of Melbourne and Monash University, Australia

ABSTRACT: Recent decades have seen substantial demutualization of financial institutions around the world, involving the conversion of accumulated communally owned wealth into private wealth. Whether driven by a quest for a more efficient organizational structure or by wealth expropriation incentives, different methods of demutualization have different implications for wealth allocation among current members and transfers of wealth to outsiders. While credit union sectors internationally have, to date, experienced few demutualizations, there are increasing incentives for such organizational change. Three alternative demutualization strategies (share issue to members plus an external capital raising, liquidation and cash distribution to members (a quasidemutualization), and merger with a listed company) recently used by Australian credit unions are analysed to highlight wealth implications, survival risks for the mutual form and potential problems arising in the demutualization process.

Keywords: organizational change, demutualization, credit unions, privatization, expropriation, efficiency

JEL codes: G21, G32, G3

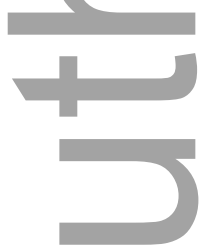

This is the author manuscript accepted for publication and has undergone full peer review but has not been through the copyediting, typesetting, pagination and proofreading process, which may lead to differences between this version and the Version of Record. Please cite this article as doi: 10.1111/apce.12128.

This article is protected by copyright. All rights reserved. 
* I am grateful to Gary Eggert, John Gilbert, David Holden, the Customer Owned Banking Association, and two anonymous referees for comments on an earlier draft. I, of course, am responsible for any errors of omission or commission. Email: kevin.davis@unimelb.edu.au

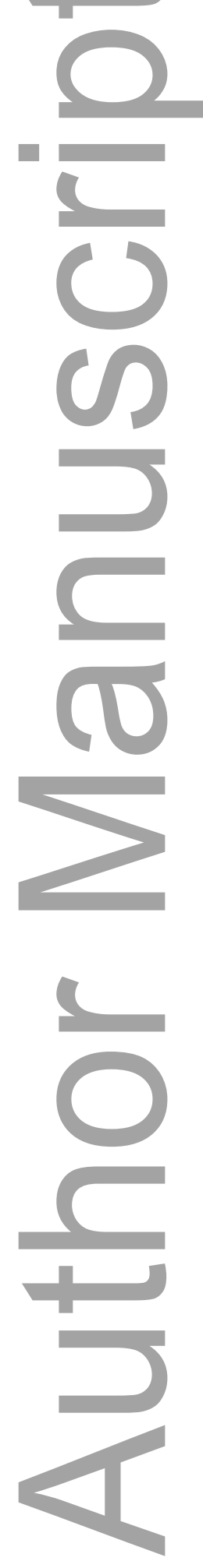

This article is protected by copyright. All rights reserved. 


\section{Introduction}

Credit unions were originally established as mutual organizations to provide financial services to individuals, who are member/owners each with one vote, linked by a 'common bond' such as employment or community. The objective was generally the imprecisely defined one of providing benefits to members, in contrast to the precisely defined 'for-profit' objective of jointstock companies.

In some countries, the credit union sector is still nascent, providing relatively basic services. Sibbald et al. (2002) provide an overview of credit union development stages. In others such as Australia it has evolved to a degree where the range of financial services provided to members (including to small businesses operated by members) is little different to that offered to retail customers by banks. But noticeably, to date, there have been relatively few cases worldwide of credit union demutualization - which involves conversion to a joint-stock, for-profit, company with tradeable shares each carrying one vote. ${ }^{1}$ This contrasts with other parts of the financial sector such as insurance and building societies (savings and loans) where mutuality was common but where widespread demutualization (both in Australia and many other countries) has meant that few mutual financial organizations (other than credit unions, and mutual / cooperative banks in Europe) remain.

This does not mean that demutualization has not been widely discussed nor that there have not been some instances of credit union demutualization. (See Davis (2007), Davis (2005), Wilcox (2006) and Crofton et al. (2012) for details). One commonly argued rationale for demutualization is that such organizational transformation is efficiency enhancing and needed to enable credit unions to remain competitive in a modern environment in which members can access financial services

1 Demutualization also involves conversion of the accumulated communal wealth of the credit union into private wealth of individual members and other participants in the process, and that is a major focus of this paper. Consequently, one of the cases included here involves such a conversion achieved by a liquidation of the credit union.

This is the author manuscript accepted for publication and has undergone full peer review but has not been through the copyediting, typesetting, pagination and proofreading process, which may lead to differences between this version and the Version of Record. Please cite this article as doi: 10.1111/apce.12128.

This article is protected by copyright. All rights reserved. 
from a wide range of alternative providers. But an alternative argument advanced to explain interest in demutualization is based on the evolution of credit unions into organizations with large amounts of communally owned wealth. Incentives then exist for expropriation by particular stakeholders of the credit union or by outsiders, because conversion of that communally owned wealth into private wealth can be achieved by demutualization (Kay 1991).

Whether the efficiency hypothesis or the expropriation hypothesis best explains past demutualizations in the financial sector is open to debate, but it should be noted that they are not mutually exclusive. Key stakeholders in a mutual organization could perceive efficiency benefits arising from demutualization as well as the opportunity to enrich themselves in the process. Similarly, key decision-makers who are convinced of the merits of the efficiency hypothesis are confronted with the issue of how to achieve a 'fair' distribution of the communal wealth and avoidance of expropriation (other than of future generations as discussed below). ${ }^{2}$

There are several forms of wealth redistribution involved in a demutualization. One is through inequities in the division of the communal wealth between existing members as well as outsiders who may participate in the process via participation in an associated capital raising. It is virtually impossible to determine the relative contributions of existing members to the accumulation of the communal wealth arising from profits made (and retained) by the mutual in transactions with members. The potential for inequities between current members is thus clear.

But recognizing that the communal wealth has been built up over time by contributions from both past and current members identifies a potentially more important form of wealth redistribution. Current members can be viewed as having 'inherited' the communal wealth from past members under an implicit contract that such communal wealth would be built upon and passed on to future members. Demutualization involves revoking the implicit inter-generational contract to the benefit of current members and the detriment of potential future members. So also does liquidating the credit union and distributing the existing communal wealth amongst current members. Also, to the extent that past members (whose membership and transactions contributed to the accumulated communal wealth) or their heirs are excluded from participating (as is typically the case) another form of wealth redistribution occurs. A case could be made that, if benefits received from

2 WOCCU (2015 not in ref list\}) includes provisions for a change of structure, such as a demutualization, of a credit union in its Model Law (requiring at least 30 per cent of members voting and 75 per cent approving) but provides no guidance on specific arrangements other than that 'no member, director or employee shall be given an opportunity to benefit in a disproportionate way relative to other members.' (p. 69) 
demutualization should reflect contributions to the current communal wealth, past members or their heirs have a right to to participate (although effective implementation would be highly problematic). $^{3}$

The objective of this paper is to examine three recent cases of conversion of communal wealth of Australian credit unions into private wealth of current members (and others) by demutualization, to identify sources of wealth redistribution involved and examine the merits of alternative demutualization approaches. ${ }^{4}$ They correspond to the alternative approaches of subscription, pure distribution, and merger demutualizations analysed in Davis (2007), although the pure distribution approach considered here also involved liquidating the credit union. While intergenerational redistribution cannot be avoided, different processes may have differential implications for wealth redistribution amongst current members and outsiders. The first case studied (Goldfields) involves a demutualization by way of issuance of transferable shares to members and a simultaneous capital raising open to both members and outsiders. The second case examined (Broadway) involves liquidation of the credit union (and transfer of deposits, loans, and some cash to another credit union) with proceeds being distributed to current members. The third case (MyState) involved merger of the credit union with a stock exchange listed, profit oriented, company and the issue of shares in the newly merged entity to existing credit union members.

Before providing a brief overview of recent trends in the Australian credit union sector to provide context for the following analysis of the three cases, the next section provides a brief overview of the arguments for and against demutualization, and potential consequences for wealth redistribution.

\section{Demutualization theories and perspectives}

The 'efficiency' hypothesis (see Rasmusen (1988), Masulis (1987), Hart and Moore (1996)) which argues that demutualization leads to a more efficient organizational structure, is founded on a number of arguments. First, demutualization, involving a change in voting rights from one per

\footnotetext{
3 Some past demutualizations of other financial institutions have involved allocating some shares to a charitable trust which, while not specifically motivated on these grounds could be interpreted as reflecting the communal wealth created and left behind by departing members for the benefit of future generations.

$4 \quad$ There have been two prior cases of credit union demutualization in Australia, SunState in 1997 and StateWest 2005, which are briefly discussed in Davis (2007). Both involved a subscription approach, which provided external investors with significant gains, and both were subsequently taken over by other, for profit, financial institutions. There have been no other demutualizations of Australian credit unions, although, as discussed later, in 2015 four small credit unions relinquished their banking licenses and became 'community bank branches' of BendigoAdelaide Bank under a franchise style arrangement.
} 
member/owner to one per share held, increases the power of owners to discipline inefficient management and boards by exercising voting power. Second, because there are now stock market prices for the entity's shares, capital market discipline can be exerted by threat of takeover. Third, observable share market prices enable management remuneration structures to be introduced which provide incentives via linking remuneration to share price performance.

Other arguments relate to the effects of the constraints imposed by the mutual structure which, once of limited import, have become significant impediments to competitive ability in a changed financial system. One is that the inability (or difficulty) of mutuals to raise external capital limits their ability to grow - particularly when regulatory capital requirements are imposed. Demutualization removes the constraint of having to rely primarily on retained surpluses to increase capital. ${ }^{5}$ It may also provide a way, when combined with a capital raising, for a mutual facing regulatory capital adequacy difficulties to overcome those, as an alternative to seeking a merger with a more strongly capitalized mutual partner. (None of the cases considered here fall into that category). A second argument is that the mutual structure may work well when members of the mutual are relatively homogenous, such that there are few conflicts regarding the credit union's objectives and how to achieve them. With no explicit profit maximization goal, products and services may be priced in ways which benefit some members at the expense of others with different usage patterns, although with homogeneous membership such cross-subsidization amongst members may relatively limited or accepted as appropriate given the common bond of membership. (For example, members who are currently depositors may accept lower interest rates which enable subsidization of current borrowing members knowing that they may be borrowers at some future time). As the membership becomes more heterogeneous such cross subsidization acts as a disincentive for those providing the subsidization to remain as members. This becomes particularly relevant if there is also a high degree of competition from profit-oriented entities who may be able to attract such members away from the mutual. Third, demutualization may enable the institution to undertake new activities which are precluded by regulatory constraints on activities of mutuals.

There are, of course, counterarguments. One group of arguments is based around the perceived negative effects of demutualized depository institutions taking on higher levels of risk. Entrenched management of mutuals may be relatively risk averse in order to protect against risk of losing perks of office. This beneficial effect may be amplified by the absence of any owner/depositor

\footnotetext{
$5 \quad$ Because regulatory capital definitions allow limited inclusion of financial instruments such as preference shares or some other forms of hybrid securities, credit unions can supplement retained surpluses as a source of capital by issue of such instruments while maintaining their mutual structure.
} 
agency problem in a mutual (since each depositor is also an owner) which can otherwise give rise to owner preferences for higher risk taking. Linking management remuneration to share prices postdemutualization may also give incentives for high risk taking. Expansion into new areas of activity post-demutualization may involve increased risks.

A second group of arguments asserts that there are some inherent advantages arising from the mutual structure which are lost upon demutualization. Generally, such advantages have been seen to arise from superior information about members, because of the common bond characteristic, enabling better loan assessment and monitoring. Also potentially relevant is the effect of close social interactions amongst members reducing the likelihood of borrower members defaulting on loans. Those perceived advantages diminish as the size of the institution increases and the common bond is widened. ${ }^{6}$

Whether increased scale is needed to reap cost efficiencies, and whether increased financial integration has reduced possible efficiencies of the mutual form are unresolved questions. Jones and Kalmi (2012) review empirical studies of scale economies in mutual and cooperative financial institutions and find that, apart from the US where economies tend to be found, and may reflect less collaboration amongst cooperatives (which is one way of achieving economies), the evidence from elsewhere is ambiguous. And Makinen and Jones (2015) find no evidence that cost efficiency advantages of mutual over commercial banks in Europe have declined over time. Jones and Kalmi (2015) find that growth in membership is not associated with worse performance of Finnish financial cooperatives. They argue that a 'new view' of the effect of ownership structure and growth on performance, which emphasizes the interrelationships between membership and member / customer behaviour and incentives, drawing on the relevance of reciprocity and trust, in contrast to the 'old view'which emphasizes property rights, is needed.

The alternative 'expropriation' hypothesis is based on recognizing that the mutual credit union creates over time a stock of communally owned wealth in the form of retained surpluses as well as the franchise value of the organization. Davis (2001) shows how, with a one-member-onevote governance structure, it is possible a majority vote of members to demutualize can occur, even if there are inherent advantages arising from the mutual structure, and which would be lost on demutualization. From demutualization, members receive as private wealth (in the form of tradable

\footnotetext{
$6 \quad$ Other possible benefits include preferential tax treatment for mutuals, provision of subsidized services by employers of members, voluntary provision of labour by members (including directors). Decision making processes and member/customer involvement with the mutual may be improved because of ownership status.
} 
shares, or cash in the case of liquidation) some part of the communal wealth, but lose the future stream of lower cost services from the mutual. The larger is the communal wealth available to be converted to private wealth and the lower the anticipated length of membership over which advantages from the mutual form may be reaped, the more likely will private interest lead to a vote for demutualization.

While demutualization ultimately requires a vote of members, profiteers (often referred to as carpetbaggers) who are not members also have an incentive to encourage demutualization of well capitalized mutuals in pursuit of private profit. By becoming members, if possible, they can stimulate an agenda for demutualization, or can do so as third parties offering advisory services to the credit union. The main benefit, however, is likely to arise not simply from participating in an allocation of shares to members, but from the ability to participate in a capital raising, open to outside investors, which often accompanies a demutualization. Because of the accumulated wealth of the credit union, purchasers of new shares can reap immediate share price gains at the expense of existing members if the issue price is below the implied value per share which has been allocated to members. Crofton et al. (2012) discuss how these concerns influenced the evolution of US regulatory determinations on allowable methods of demutualization.

To see the consequences of combining a demutualization with a capital raising, suppose that the mutual has accumulated wealth of $\$ W$, and $m$ shares are allocated to members. ${ }^{7}$ Without any external capital raising, the members' shares would be worth $\mathrm{W} / \mathrm{m}$ each. However, suppose $\$ \mathrm{Z}$ new funds are also raised from outside investors through the issue of $n$ additional shares at an issue price of $\mathrm{Z} / \mathrm{n}$. After the issue there will be $(m+n)$ shares on issue. In the absence of any additional value creation from the demutualization per se, the total wealth of the entity is $\$(W+Z)$ and the post-issue share price will be $(W+Z) /(m+n)$. If the external shares are issued at a discount to the value of shares issued to members $(Z / n<W / m)$, it is straightforward to demonstrate that $Z / n<(W+Z) /(m+n)<W / m$. That is, the post-issue share value is above the issue price (ie 'stag' profits occur for external investors) and the value of members' shares are diluted through a transfer of wealth to external investors. Note that if the valuation of shares allocated to members $(\mathrm{W} / \mathrm{m})$ is based solely on the balance sheet figure of net assets but there is substantial 'franchise' value, then even if external shares are issued at the same price $(\mathrm{Z} / \mathrm{n}=\mathrm{W} / \mathrm{m})$, there will be a transfer of value to external investors.

\footnotetext{
$7 \quad$ This wealth value should include any 'franchise' value as well as the accumulated financial wealth recorded in the balance sheet.
} 
If the capital raising enables investment in positive NPV projects or the demutualization itself creates value, then the total wealth of the entity will exceed $W+Z$, moderating or offsetting any such wealth transfer. It thus becomes important to assess both the terms of such a capital raising as well as the prospects for a demutualization and capital raising to involve value creation.

\section{The Australian credit union sector}

Around 20 per cent of the Australian population are members of a credit union, but the sector and individual institutions are small relative to the banking sector and the banks involved with which they compete in retail finance markets. Credit Union deposits are around 10 per cent of total deposits, and there are, in 2015 just over 90 credit unions, with many mergers having reduced the number from over 700 in the 1960s. Accompanying that trend has been the expansion or removal of common bonds by many institutions, and most lending has been, for several decades, primarily residential mortgage lending. Since 2012 some of the larger credit unions have taken advantage of a regulatory change enabling them to use the term 'mutual bank', with apparent connotations in the public mind of greater safety and fuller range of banking services range, even though deposit insurance applies equally to banks and credit unions (since its introduction in 2008) and credit unions can provide a full range of retail banking services. (These include mortgage and personal loans, credit cards, deposits, payments services including cheques and electronic transfer facilities and ATM access, and other services such as foreign exchange conversion via agency arrangements). Also noteworthy has been the recent (2015) decision of four credit unions to become 'community bank branches' under a franchise arrangement with BendigoAdelaide Bank (which itself was formerly a mutual building society until demutualization in the 1990s). ${ }^{8}$

Australian credit unions are subject to essentially the same regulation as banks, including risk weighted capital requirements, and have built up significant capital bases (in the form of retained earnings, ie communal wealth) such that capital ratios are generally significantly higher than those of the banks. The prudential regulator has indirectly encouraged mergers within the industry, including the application of strict board skill requirements and compliance obligations which are onerous for small credit unions to meet. This has contributed to decisions of smaller credit

\footnotetext{
8 The arrangement essentially left the mutual entities retaining their accumulated net wealth, relinquishing their banking licences, and becoming a mutual operating company providing members with financial services of the bank under a franchise style arrangement. Because the communal wealth is not privatized this does not qualify as a demutualization.
} 
unions to merge. Remuneration of directors is substantially more common than not, particularly for larger credit unions.

In the early 1990s, Australian credit unions lost their exemption from company tax. Moreover, under Australia's dividend imputation tax system they are, arguably, subject to a tax disadvantage relative to banks due to inability to distribute to members the tax ('franking') credits which arise from company tax payments.

While credit unions have had difficulty sustaining their overall share of retail loan and deposit markets, the sector has, over recent decades, been able to generate sufficient surpluses to grow capital at a rate more than sufficient to meet regulatory requirements arising from larger scale. The decisions to demutualize of the three credit unions considered in the next section should thus be viewed in the context of them being adequate performers in a sector not in terminal decline, but one facing ongoing competitive challenges limiting its growth rate.

\section{Goldfields: a 'standard' demutualization}

A common approach to demutualization for both credit unions and other financial institutions has been to link the demutualization to the raising of new capital, as in the example just discussed. In this approach members will be allocated some number of shares (free of charge), and will have, as may outsiders, the opportunity to subscribe for extra shares. This was the approach adopted by Goldfields Credit Union when it demutualized in May 2012, and listed on the Australian Stock Exchange under the name Goldfields Money.

Goldfields Credit Union was established in 1982 with a community common bond of the Goldfields region of Western Australia. In the prospectus, dated 14 February 2012, (Goldfields Credit Union 2012) it was advised that individuals who were members as at 30 March 2012 would, subject to approval of the demutualization by a vote of members at that date, be eligible to receive an allocation of free shares in the credit union and make priority applications to subscribe for new shares in the company. The intention to demutualize, including that members would receive free shares worth approximately $\$ 2,000$ had been announced much earlier on November 4, 2010 (Goldfields Credit Union and Patersons 2010). No new members were admitted after the announcement. There were 2,675 members at June 2011, and membership had been declining slightly (at June 2004, membership was 2,984). Like many other financial institutions, growth and profitability had fallen somewhat after the financial crisis, but capital adequacy was high, as shown in Table 1. However, rapid growth such as seen in 2011, and substantial expansion plans (to beyond 
the common bond region), would ultimately reduce capital adequacy and prove a constraint on achieving those plans.

Table 1 - Goldfields Credit Union financial performance 2004 - 2011

$\begin{array}{lcccccccc}\text { Year } & 2004 & 2005 & 2006 & 2007 & 2008 & 2009 & 2010 & 2011 \\ \text { Risk weighted Capital Ratio } & \text { na } & \text { na } & \text { na } & \text { na } & 20.1 & 25.5 & 24.8 & 21.1 \\ \text { Return on Equity } & 13 \% & 11 \% & 12 \% & 11 \% & 14 \% & 7 \% & 7 \% & 6 \% \\ \text { Total Asset growth rate } & \text { na } & 13 \% & 9 \% & 4 \% & 9 \% & -2 \% & 9 \% & 27 \%\end{array}$

Source: Goldfields Credit Union, Annual Reports

In the prospectus, each of the assumed 2675 members would receive 2,303 shares for a total issuance of $6,160,525$ shares of $\$ 1$ par value each. Nine million extra shares at a price of $\$ 1$ each were made available for subscription by outside investors (and members could also participate in this process with priority allocation promised). For every two shares purchased, investors would also receive, for no extra cost, an unlisted option to purchase additional shares at an exercise price of $\$ 1.50$, anytime over the subsequent seven years, with each option valued by the company at $\$ 0.407$ each. ${ }^{9}$ Table 2 sets out an extract from the pro-forma financial statements and information (from the prospectus) about share capital.

Total costs of the demutualization and capital raising of $\$ 9$ million were estimated in the prospectus to be $\$ 1.86$ million with $\$ 0.7$ million attributable to the demutualization and $\$ 1.16$ million to the capital raising. The capital raising was underwritten by Patterson stockbrokers and passed on to a number of individuals and institutions as sub-underwriters.

In the event, the allocation of shares was as shown in Table 3, with 2,643 members receiving the free allocation of 2,303 shares each, and with the top 20 investors holding 31.6 per cent of the shares (with an average of around 250,000 shares each).

$9 \quad$ The valuation was made using a binomial model with an assumed volatility of 50 per cent p.a.and risk free rate of 3.4 per cent p.a. (Future dividends were stated in the 2012 Annual Report as being assumed to be zero for purposes of the valuation). The prospectus outlines how the terms of the options would be adjusted for rights and bonus issues. 


$\begin{array}{lll} & \begin{array}{l}\text { Pre } \\ \text { Demutualization }\end{array} & \begin{array}{l}\text { Post } \\ \text { Demutualization }\end{array} \\ \text { Assets } & 58.2 & 66.5 \\ \text { Deposits } & 54.4 & 52.4 \\ \text { Equity } & 5.8 & 14\end{array}$

Share Capital

Accounting Treatment

Members shares

10700

Shares issued free to members

6160525

valued at $\$ 6,160,525$

Shares issued to subscribers

9000000

valued at $\$ 7,169,400$

Shares granted to CGU

Community Trust

580000

not included

Unlisted Options issued to

unlisted option reserve

subscribers

4500000

$\$ 1,830,600$

Source: Goldfields Prospectus

http://www.asx.com.au/asx/statistics/displayAnnouncement.do?display=pdf\&idsld=01272855

Table 3 - Initial share distribution: Goldfields Credit Union

$\begin{array}{llcc}\text { Range of Holdings } & \text { Number of Holders } & \text { Number of shares } & \text { Average Holding } \\ <1000 & 0 & 0 & \text { n.a. } \\ 1001-5000 & 2631 & 6,238,823 & 2,371 \\ 5001-10000 & 53 & 409,946 & 7,735 \\ 10001-100000 & 102 & 4,160,757 & 40,792 \\ 100001+ & 19 & 4,857,829 & 255,675\end{array}$

Source: ASX initial holdings disclosure,

http://www.asx.com.au/asxpdf/20120518/pdf/426bx34980t6jq.pdf 
Was the allocation policy a fair one? While 'fairness' is a difficult concept to define precisely, in this context one interpretation is the extent to which existing members, rather than outsiders, received the private wealth benefits arising from the demutualization.

In attempting to answer this question, it is important to note that the market value of the equity of an organization is not necessarily equal to the accounting (book) value of its equity. Franchise value, which is the ability of the entity to generate income in excess of the required return of shareholders, also needs to be considered. That franchise value could reflect past profitable investments, or future profitable growth opportunities. Unfortunately, in the absence of a stock market price pre-demutualization, it is difficult to assess the likely market value. It is partly for this reason that Davis (2005) argues that demutualization (if it is to occur) and capital raising should be undertaken as a two step process. By first demutualizing and gaining information about the overall value of the credit union from the resulting market prices at which shares trade, it is then possible to determine an appropriate price for making a share issue to external investors and existing shareholders to raise additional capital. While it is typically the case that such secondary issues will be made at some discount to the market price, and thus involve some transfer of value from existing shareholders to investors in the offer, there is less risk of excessive transfers of value. More generally, such a process transfers all of the current value of the entity to existing members via the first stage allocation of shares to members. This is equivalent to the 'free distribution' model proposed but abandoned by US mutual thrift and credit union regulators discussed in Crofton et al. (2012)

One possible way to examine how much value is transferred from existing members to subscribers to the issue (many of whom may be members) is to compare the stock market value of the company after demutualization and stock exchange listing to the book value of equity immediately after the demutualization. The difference represents the original franchise value plus the value created by demutualization and the capital raising. If it is assumed that the capital raising was not value creating (an extreme assumption), then value transferred to investors equals the number of shares they receive multiplied by the difference between the post-listing share price and the par value of shares.

In the case of Goldfields, the share price on the first day post listing ranged between $\$ 1$ and $\$ 1.02$ versus a $\$ 1$ subscription price. This suggests virtually no transfer of value to the investors in the capital raising, nor any significant net value added created by the injection of capital by those 
investors. ${ }^{10}$ That conclusion does not, however, take into account the issue of 4.5 million 'free' options to investors which were valued in the prospectus at $\$ 0.407$ each, presumably at an assumed share price of $\$ 1$ (the par value). ${ }^{11}$ The market value of the options, post listing, although unobservable (because they were not listed on the exchange), needs to be considered as part of the net gain to investors. At the prospectus valuation of $\$ 0.407$ this amounts to a $\$ 1.8$ million unrealized gain. Thus external investors appear to have made a gain of $\$ 1.8$ million on an investment of $\$ 9$ million or 20 per cent return. ${ }^{12}$

How did the members fare? Most received only the free allocation and thus an initial communal wealth of $\$ 5.8$ million was converted into 6.16 million shares worth approximately $\$ 1.00$ each, or a total value of $\$ 6.16$ million. Their implied gain was thus $\$ 0.36$ million, or $\$ 0.94$ million if the 580,000 shares allocated to the CGU Community Trust are also included. Thus most (over twothirds) of the net benefits from demutualization accrued to the outside investors. Is this appropriate? The answer depends on how much of the apparent value creation reflected the inherent 'franchise value' of the credit union (which arguably should accrue to current members) versus the creation of new profitable opportunities due to the increase in size from outside investor injections of equity capital (which arguably should accrue at least in part to those investors). Unfortunately it is not possible to determine the relative importance of these two factors given the absence of a market price for the credit union equity prior to the contributions of the external investors. $^{13}$

In addition to the private gains to external investors and members, there were substantial expenses involved in the demutualization ( $\$ 0.7$ million) and raising of capital (\$1.16 million). These amounts (which suggest that the process was a high cost exercise) can be interpreted as a third form

In the first ten days after listing 1.36 million shares (or around 9 per cent of total shares on issue) were traded. While the share price increased to $\$ 1.29$ over the next two weeks, it had reverted to around $\$ 1$ within four weeks

11 Precise details of the option value calculation are not provided in the prospectus.

12 Because the options were not listed, there is no market price available for them, and the prospectus valuation is used in this calculation.

13 A further complication arises from the existence of unused franking (tax) credits in the company's franking account balance. Australian companies are able to distribute tax (franking) credits, arising from company tax payments, to shareholders when cash dividends are paid At June 2011, the balance was \$2.37 million. As a mutual, there was no way for these tax credits to be distributed to members. Demutualization makes distribution possible through payment of dividends. Estimating the net benefit to shareholders of this change is however problematic. 
of private gains from the demutualization process in the form of fees accruing to the corporate advisors managing the process - although expenses incurred by them in the process would reduce the net gain.

It has already been noted that most members received only their free allocation, with the top 20 investors being allocated around 250,000 shares on average. Members were to have priority in the allocation process, so some of these are likely to have been members - although information on the allocation process is not publicly available. And in the official register of holdings of the top 20 investors provided by the ASX, most of the investors are not individuals - but self managed superannuation funds or private companies. ${ }^{14}$ Notably, the four non-executive directors of the credit union post-demutualization were reported in the notification to the ASX of initial holdings of directors as each holding between 20 and 55 thousand shares. ${ }^{15}$ They did not participate substantially in the share subscription, indicating that this was not a case of those insiders expropriating the communal wealth. But nevertheless, much of the private wealth unlocked by the demutualization ended up in the hands of outsiders and a few members - suggesting that most members were not aware of the private gains to be made, or unable to finance the required investment. $^{16}$

\section{$3 \quad$ Broadway: liquidation and distribution}

In November 2008, the deposits and loans (and some cash) of Broadway Credit Union were transferred to Gateway Credit Union in a partial transfer of engagements, after which Broadway Credit Union was liquidated and remaining assets (cash) of around \$22 million distributed to the approximately 1,100 members (around $\$ 22,000$ each).

The terms of the acquisition were reported in Gateway's 2009 Annual Report as shown in Table 4. The Board of Gateway perceived it as being a good transaction in that the value of assets received exceeded the value of liabilities taken on by $\$ 400,000$. It also meant a significant increase in

\footnotetext{
14

The official register indicates that none of the top 20 investors previously held shares in the company, suggesting that none were members (who each received the free allocation) although this is likely to be either a reporting error or resulting from member/investors having the shares registered in an alternative name.

15 Two other directors resigned after the demutualization and before ASX listing.

16 As a postscript, the share price had fallen to $\$ 0.75$ in August 2015 , no dividends had been paid by the demutualized company, despite a tripling of total assets relative to pre-demutualization, annual profits in the three years to June 2015 were less than half the pre-demutualization levels.
} 
the size of the credit union. However, the effect was to reduce the capital ratio of Gateway, since only the $\$ 400,000$ would be counted as capital, while around $\$ 42$ million of assets were added to the balance sheet.

Table 4 - Gateway Credit Union acquistion of Broadway's assets and liabilities

\$'000

Cash

11,882

Loans and advances

30,214

Deposits

$-41,691$

Payables

$-3$

Member shares

$-2$

Fair value of net identifiable assets and

liabilities

400

Purchase Price

Discount on acquisition

400

Source: 2009 Annual Report, Gateway Credit Union

Broadway Credit Union had experienced a declining membership since the start of the 1990s but had grown substantially in terms of total assets until around 2000, after which assets and deposits had declined. See Figure 1. Partly responsible for these trends was a decision by the Credit Union to operate solely as a vehicle for savings and loans without provision of payments or other related services provided by other credit unions and banks. 


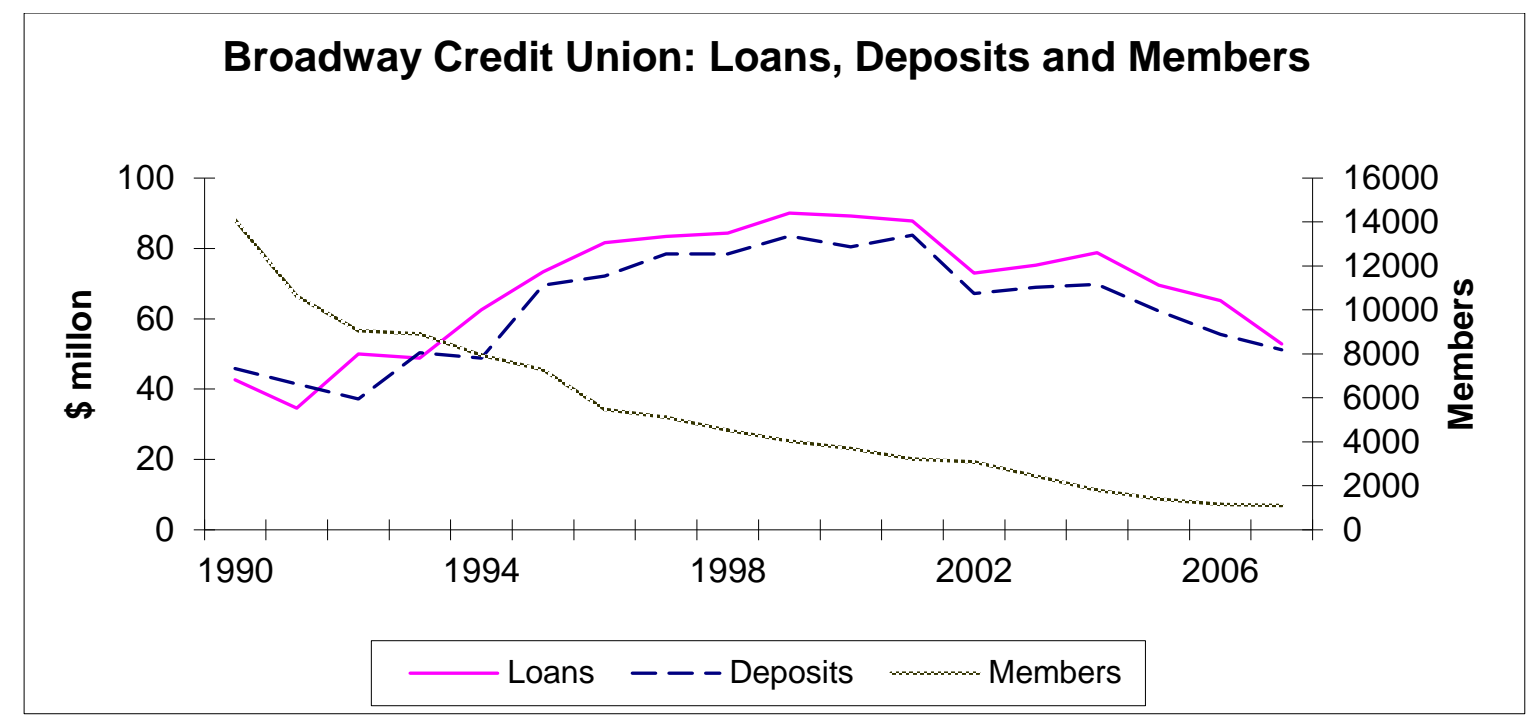

Figure 1 - Broadway Credit Union: measures of size.

Source: KPMG Financial Institutions Performance Survey (various issues)

The credit union had been profitable over this period with retained surpluses leading to growth in its net assets (members funds) as shown in Figure 2. Return on equity (ROE) declined as the capital/assets ratio of the credit union increased from around 10 per cent at the start of the 1990s to around 16 per cent at 2000 to almost 30 per cent just prior to demutualization. Net assets per member increased markedly during the 2000 s, as membership declined, to around $\$ 20,000$ just prior to the demutualization, creating significant private incentives to convert this communal wealth into private wealth.

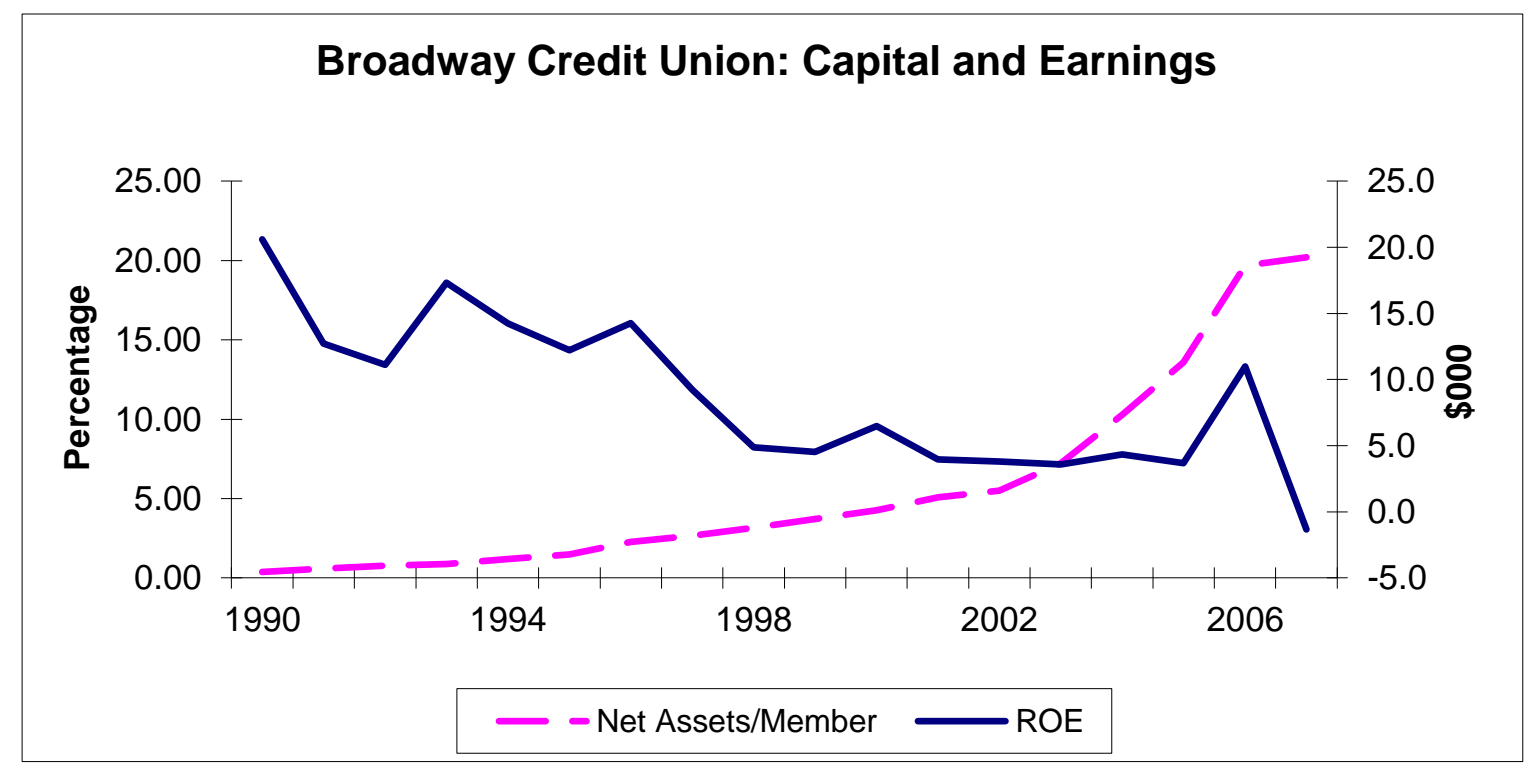


Figure 2 - Broadway Credit Union capital and earnings.

Source: KPMG Financial Institutions Performance Survey (various issues)

The proposal to do so, by way of a transfer of loans (and cash) and deposits to a third party and subsequent liquidation, was put to members in an information statement in late 2006 (Broadway Credit Union 2006). That proposal envisaged a transfer of loans and deposits to Savings and Loans Credit Union, which had been selected based on an evaluation of expressions of interest and tenders in response to an Information Memorandum. The proposed transfer involved Savings and Loans taking on deposit liabilities from Broadway valued at $\$ 55.965$ million and loan assets valued at $\$ 61.756$ million and paying the difference (\$5.791 million) to Broadway. Ultimately, the negotiations on that deal failed and the transfer was made to Gateway Credit Union and involved significantly lower loan and deposit amounts (due to a decline in Broadway's balance sheet size) plus a cash transfer from Broadway to Gateway (see Table 4). ${ }^{17}$

The transfer of $\$ 42$ million of assets was only a partial transfer of the total assets of Broadway. At June 2007 (latest figures available) total assets of Broadway were \$75.6 million, deposits were $\$ 51.6$ million and net assets (equity) were $\$ 22.3$ million. Assuming that at November 2008 deposits and assets had both shrunk by around $\$ 10$ million (and \$41 million of each transferred), there remained some $\$ 22$ million of net assets communally owned by members of the credit union. At June 2007 there were 1,104 members or around \$20,000 of net assets per member. In the subsequent liquidation, these funds were distributed to the members. This took the form of a liquidating dividend (paid in two tranches - the 2006 Information Memorandum proposed an initial distribution of $\$ 15,455$ to each member of which $\$ 6,869.75$ would have valuable tax credits attached.

The wind-up of Broadway Credit Union achieved the outcome of converting the communal wealth into private wealth of existing members with no leakage to outsiders other than the expenses of the process which were estimated in the Information Statement to be $\$ 1.768$ million. The rationale for the wind-up of the Credit Union was the declining membership and concerns about future profitability. While return on equity (roe) over the previous decade at around 5 per cent had been low by industry standards, this needs to be considered in the context of the low leverage of the credit union. Return on Assets (roa) had averaged in the region of $0.7-0.8$ per cent, which was no worse than the credit union industry average for the period.

\footnotetext{
$17 \quad$ Negotiations between Broadway and Savings and Loans broke down, and Gateway was instead chosen to receive the transfer of business.
} 
The declining membership, in conjunction with the growing communal wealth created conditions conducive to members voting for a wind-up of the business, despite current profitability, rather than alternative strategies such as merger with another credit union. ${ }^{18}$ The small number of remaining members profited handsomely from the distribution of funds. Notably, there was no distribution made (or proposed) to past members, whose transactions with the credit union had contributed to the build-up of communal wealth since its establishment in 1963 . While it is not known how many of the remaining members were long term members and how many relatively new, it is worth noting that around $\$ 15$ million of the net assets of the credit union had been built up by 2000 , when membership was still around 4,000 . While legally, current members were able to vote to wind-up the entity and the directors able to recommend a distribution of net assets to current members only, a moral case could be argued that past members warranted some share in the distribution of net assets.

While directors of the credit union benefited from the wind-up in their capacity as current members, there is no evidence of insider gains from the process. The wind-up resolution involved approval of redundancy payments to the directors totaling only $\$ 73,000$ (and distributed amongst the four directors on the basis of years of service). With many credit unions of comparable size paying total annual directors fees of the same order of magnitude, this does not appear unreasonable.

\section{$5 \quad$ The MyState-Perpetual trustees merger}

In September 2009, MyState Financial Credit Union (with 117,000 members) merged with the ASX listed Tasmanian Perpetual Trustees (TPX) , with the merged entity named MyState Limited trading on the ASX under that name (and code MYS) from 24 September 2009. Shareholders in TPX received one share in MYS in exchange for each TPX share held, while each member of MyState received 387 shares. MYS was structured as a holding company with the credit union activities and the trustee company activities initially operating as subsidiaries. The Tasmanian State Trustee legislation had been amended to limit the maximum beneficial shareholding of any investor in MYS to 10 per cent (although plans for Federal legislation to subsume State legislation would see this limit increase to 15 per cent - which would be consistent with provisions of the Banking (Bank Shareholdings) Act.

\footnotetext{
18 Informal communications with members of the credit union industry indicate that there was no shortage of potential willing merger partners.
} 


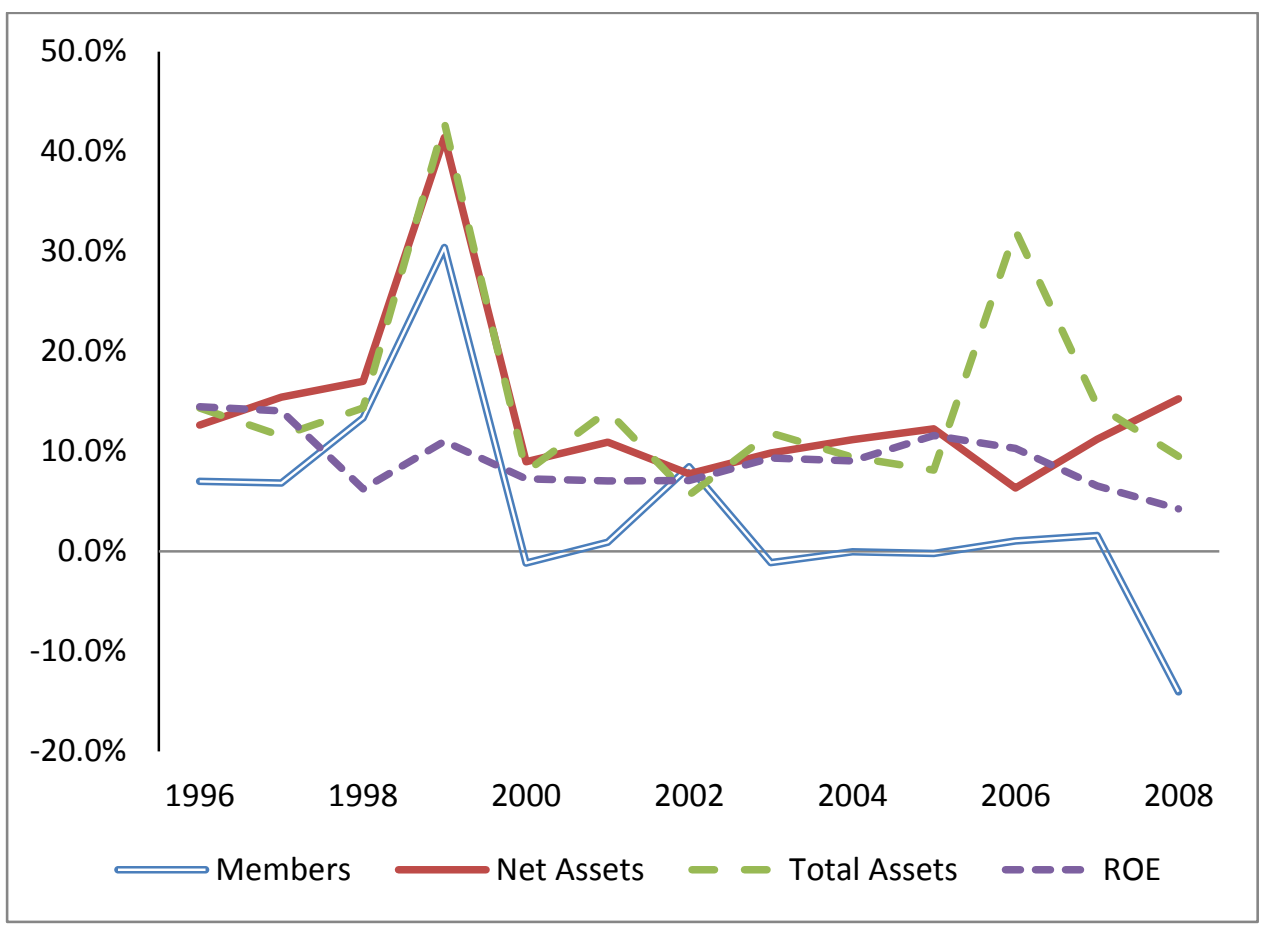

Figure 3 - MyState Credit Union pre-merger growth rates.

Source: KPMG Financial Instutitons Performance Survey (various issues)

The proposed merger had been announced on 10 October 2008, although the terms were not finalized until June 2009 and announced in (MyState Financial 2009). ${ }^{19}$ Members of My State Financial voted to approve the merger in August 2009, although a previous attempt to demutualize one of the predecessor credit unions (Connect) had failed in 2003, when opposed by a majority of members. Mystate Credit Union was created by the merger of two long-standing credit unions (Connect and Island State) on 1 July 2007, and the aggregated performance of the credit union and its pre merger successors is shown in Figure 3.

The main arguments advanced by MyState management in support of the demutualization and merger with TPX were based around increased strength and scale of the merged organization, although the consequences for each member of receiving approximately 380 shares in MYS was highlighted. ${ }^{20}$

\footnotetext{
19 New members of MyState joining after October 10, 2008 were not eligible to receive shares in the merged entity.

20 While the information memorandum did not place a dollar value on the 380 MYS shares to be received, the fact that each TPX share, then trading at around $\$ 2.70$, would convert to one MYS share indicated a value of around $\$ 1,000$.
} 
The independent experts (the advisory firm PKF) assessed the value of MyState Financial to be $\$ 117.3$ million, and the consideration to be received by members ( 67.5 per cent of the merged entity as having value of $\$ 139.2$ million). At June 2008 , MyState had net assets of $\$ 120.2$ million. The valuation method adopted by the independent expert was to apply a multiple of around 10 (based on comparables) to a sustainable earnings stream around $\$ 12$ million (which was the profit figure for 2006-7, while it was $\$ 13.8$ million for 2007-8). This implied a net tangible assets multiple of approximately unity - lower than for comparables.

TPX had a market capitalization of $\$ 65.5$ million and net assets of $\$ 33$ million at the end of 2008. Prior to the merger announcement TPX shares traded at $\$ 3.75$ on 9 October 2008. In June 2009 they were trading at $\$ 2.70$. In 2007-8 profits were $\$ 7$ million, down from around $\$ 7.5$ million in the previous two years. Just under 22 million shares were on issue. The independent experts arrived at a valuation of TPX close to the current market capitalization, by applying a multiple of around 12 to maintainable earnings of over $\$ 4$ mill and determining that there were approximately $\$ 14$ million of surplus assets. This involves a multiple to NTA of approximately 2 compared to that for MyState of around unity. While there may be grounds for this disparity, and the non-realizability of the MyState value without demutualization is argued by the independent experts to be such a reason, this disparity seems large.

Following the merger there would be 67.5 million shares on issue, 22 million held by former TPX shareholders and 45.5 million held by MyState members. By adding a premium to the consolidated value for expected synergies of between $\$ 20-25$ million, the independent experts arrive at a total valuation of $\$ 200$ million plus such that the approximately $2 / 3$ share of the total held by MyState members meant a premium relative to the assessed value of MyState of between 17.6 and 19.6 per cent. (Of course, if a similar NTA multiple had been used for both, the net effect would have been a discount). In the event, MYS shares commenced trading at around $\$ 3.00$ which is close to the value per share assessed by the independent experts.

Alternative approaches could be used to consider the merits of the terms of the merger. One would be a comparison of the expected contribution of each entity to the total profits of the merged entity. With MyState profitability at around \$12 million p.a. and TPX at around \$7 mill p.a., an outcome giving MyState members approximately 2/3 of the combined entity seems reasonable. Using market capitalization of TPX of $\$ 65.5$ million and book value capitalization (net assets) of MyState of $\$ 120$ million also would suggest that a $2 / 3$ share is not inappropriate - although the validity of such a comparison requires the assumption of an implied market/book ratio for MyState of around unity. 
MyState Financial had available some $\$ 37.5$ million of tax (franking) credits which could not previously be distributed to members, but which the merger would make available for distribution to shareholders. Placing a value on these is difficult, since the value depends upon the marginal tax rate of shareholders. However, using reasonable assumptions the value seems unlikely to exceed \$8 million (and may be less) hence ignoring them in the valuation process (or incorporating them as part of the projected 'synergies') is not unreasonable.

Overall, while the potential exists for outsiders to receive a significant part of the credit union value through demutualization by way of merger, the MyState demutualization process appears to have avoided such an outcome. This assessment can be checked by examining whether TPX shareholders made abnormal gains through share price changes as a result of the merger although the length of time between announcement and completion of the merger makes it difficult to disentangle effects of the merger from other exogenous influences on share prices. From the date of the merger plan announcement in October 2008 (when TPX shares were trading at around \$3.75), the share price fell much in line with the ASX Financials Index for around 6 months, subsequently underperforming somewhat to reach \$2.70 in June 2009 when the Information Booklet was released. Taking that latter figure as a benchmark, exchange of a TPX share into a MYS share which commenced trading at around $\$ 3.00$ gives a benefit to TPX shareholders of around 10 per cent, which on a market capitalization of around $\$ 65$ million equates to a gain of around $\$ 6.5$ million. This could reasonably be interpreted as an upper bound estimate ${ }^{21}$ and is only around 5 per cent of the pre merger net assets of MyState.

Thus, the MyState demutualization appears to have avoided significant value transfer to outsiders at the expense of current members. However, it did not obviate the wealth transfer to current members from past and/or future members through the conversion of communal wealth passed on by past members for the benefit of current and future members into private wealth of current members. ${ }^{22}$

\section{Conclusion}

$21 \quad$ However, the possibility should not be discounted that the share price of TPX would have fallen further in the absence of the merger proposal, thereby increasing the value of the merger to TPX shareholders.

22 As a postscript, the share price had climbed to the mid four dollar range in 2015, a takeover of a listed building society (The Rock) had occurred, giving increased geographical diversification, had occurred in December 2011, and by June 2015 total assets of the banking division had approximately doubled since the demutualization. 
The three examples of credit union demutualization discussed here illustrate both the risk to survival in the mutual form faced by mutuals which accumulate significant communal wealth, as well as the potential for expropriation of that communal wealth into private wealth by both insiders (current members) and outsiders.

The Goldfields demutualization (issuing shares to members in conjunction with an external capital raising) provides an example of the problem that unless the true market value of the organization is established before an external capital raising is made, there can be a significant transfer of value to outsiders through the underpricing of shares issued via the capital raising. In the Goldfields case, the underpricing was not reflected in the listing price of the shares, because of the provision of 'free' options to the external investors. But whether the net gains to outside investors reflected a transfer of value (due to inherent 'franchise value' not being reflected in the book value of equity, or only arose from the injection of new capital enabling future potential expansion, cannot be determined.

The Broadway demutualization (by way of partial transfer of business and liquidation) highlights the incentives for current members to agree to closure of a profitable business (albeit one which was facing business challenges) when there is substantial personal gain available. While current members undoubtedly contributed, through their patronage of the business, to some part of the accumulation of communal wealth, their moral entitlement to the whole of that wealth is certainly open to debate. This case study provides a good example of the dilemma examined in (Davis 2001) where private wealth acquisition incentives could lead to members voting to wind up a profitable mutual or convert it to a joint stock form (thereby converting communal into private, transferable, wealth) even if that involves a loss of operating efficiencies. (In this case, that potential loss was offset by the transfer of members' business to another credit union).

The demutualization by way of merger with a joint stock company undertaken by MyState Financial appears to have avoided the transfer of significant value to outsiders. The reason for this result is that the process involved a valuation of both participating entities (MyState and TPX) and allocation of shares in the merged entity to the owners of each based on the relative value contributed by each entity. Regardless of whether the rationale for the merger - that economic benefits would result - was valid or not, the private wealth gains for members if the merger was approved no doubt helped induce a vote in favour.

Perhaps the most fascinating aspect of these three demutualizations is that insiders in the form of directors and management did not appear to obtain excessive direct financial benefits from 
the process. ${ }^{23}$ There do not appear to have been significant excessive payouts to retiring directors or staff, nor significantly above average allocations of shares to them. Thus the hypothesis of 'expropriation' of communal wealth by insider decision-makers does not appear to be supported in these cases. That suggests that in the case of Goldfields and MyState, insiders were of the view that efficiency gains were available from the increased scale and scope of activities accessible by demutualization.

However, for executives and directors with ambitions to expand the scale and scope of their entities operations, the private member wealth benefits from demutualization undoubtedly made gaining member/shareholder approval for such expansion plans significantly easier. In the case of Broadway, the ability of members to join an alternative credit union and obtain a private wealth benefit from liquidating the credit union would also have made this more attractive financially to members than the alternative of a merger with another credit union.

Whether the conversion of communal wealth to private wealth for the current members involved in these demutualization processes was morally appropriate or value adding from a social perspective (by enabling more efficient operations as a joint stock firm or, in the case of Broadway, closing down an entity perceived to have poor future prospects) is another question.

\section{REFERENCES}

BROADWAY CREDIT UNION, 2006, Information Statement to Broadway Credit Union Members.

CROFTON S. O., DOPICO L. G. and WILCOX, J., 2012, 'Conversions and capital of mutual thrifts:connections, problems, and proposals for credit unions', Essays in Economic \& Business History, XXX, 31-48.

DAVIS K., 2001, 'Credit union governance and survival of the cooperative form', Journal of Financial Services Research, 19, 197-210.

DAVIS K., 2005, 'Credit unions and demutualisation', Managerial Finance, 31, 6-25.

DAVIS K., 2007, 'Australian credit unions and the demutualization agenda', Annals of Public and Cooperative Economics, 277-300.

GOLDFIELDS CREDIT UNION, 2012, Prospectus in relation to the offer of securities in Goldfields Credit Union. 
GOLDFIELDS CREDIT UNION \& PATERSONS, 2010, 'Goldfields Credit Union announces proposed demutualisation, ASX listing', Media Release, 4 November.

HART O. and MOORE J., 1996, 'The governance of exchanges: members' cooperatives versus outside ownership', Oxford Review of Economic Policy, 12, 53-69.

JONES D. C. and KALMI P., 2012, 'Economies of scale versus participation: a co-operative dilemma?' Journal of Entrepreneurial and Organizational Diversity, 1, 37-64.

JONES D. C. and KALMI P., 2015, 'Membership and performance in Finnish financial cooperatives: a new view of cooperatives', Review of Social Economy, forthcoming\{?further details\}.

KAY J., 1991, 'The economics of mutuality', Annals of Public and Cooperative Economics, 62, 310318.

MAKINEN M. and JONES D. C., 2015, 'Comparative efficiency between cooperative, savings and commercial banks in Europe using the frontier approach', Annals of Public and Cooperative Economics, 86, 401-420.

MASULIS R., 1987, 'Changes in ownership structure: conversions of mutual savings and loans to stock charter', Journal of Financial Economics, 18, 29-59.

MYSTATE FINANCIAL 2009, Information Booklet.

RASMUSEN E., 1988, 'Mutual banks and stock banks', Journal of Law and Economics, XXXI, 395-421.

SIBBALD A., FERGUSON C. and MCKILLOP D., 2002, 'An examination of key factors of influence in the development process of credit union industries', Annals of Public \& Cooperative Economics, 73, 399-428.

WILCOX J., 2006, Credit Union Conversions to Banks: Facts, Incentives, Issues and Reforms, Madison WI, Filene Research Institute. 


\section{University Library}

\section{- M M N E R VA A gateway to Melbourne's research publications}

Minerva Access is the Institutional Repository of The University of Melbourne

Author/s:

Davis, $\mathrm{K}$

Title:

CHANGING ORGANIZATIONAL FORM: DEMUTUALIZATION AND THE PRIVATIZATION OF COMMUNAL WEALTH - AUSTRALIAN CREDIT UNION EXPERIENCES

Date:

2016-12-01

Citation:

Davis, K. (2016). CHANGING ORGANIZATIONAL FORM: DEMUTUALIZATION AND THE PRIVATIZATION OF COMMUNAL WEALTH - AUSTRALIAN CREDIT UNION EXPERIENCES. ANNALS OF PUBLIC AND COOPERATIVE ECONOMICS, 87 (4), pp.603-621. https:// doi.org/10.1111/apce.12128.

Persistent Link:

http://hdl.handle.net/11343/290969 